\title{
CRITÉRIOS PARA AFERIÇÃO DO ERRO DE PROIBIÇÃO NO DIREITO PENAL ECONÔMICO: DISTINÇÃO INSE E MERE PROHIBITA
}

CRITERIA FOR THE ENFORCEMENT OF THE BAN ERROR IN ECONOMIC CRIMINAL LAW: DISTINCTION IN SE AND MERE PROHIBITA

\author{
Andréa Walmsley Soares Carneiro ${ }^{1}$ \\ Faculdade Damas/PE
}

\section{Resumo}

O objetivo do presente estudo é compreender como se aplica a teoria do erro de proibição aos crimes econômicos em razão da distinção entre os delicta in se e os delicta mera prohibita. As hipóteses foram analisadas em duas perspectivas: 1.) definição da influência dos conceitos de mala in se e mera prohibita na classificação dos tipos penais e na diferenciação entre direito penal de justiça e direito penal secundário e na compreensão do direito penal econômico; 2.) observação da influência que a mudança de paradigmas causa no entendimento da teoria do erro de proibição nos crimes econômicos. Conclui pela necessidade de alterar as balizas de análise do erro de proibição, traçando novas perspectivas sob o enfoque do direito penal econômico, com destaque ao papel exercido pela amplitude do conhecimento do injusto.

\section{Palavras-chave}

Direito Penal Econômico. Delicta In Se e Delicta Mera Prohibita. Erro de Proibição.

\section{Abstract}

${ }^{1}$ Professora da Faculdade Damas. Doutora em Direito pela Universidade Federal de Pernambuco. Procuradora da República. 
The objective of this study is to understand how is applied the ban error theory to the economic crimes because of the distinction between delicta in se and delicta mera prohibita. The hypotheses were tested in four perspectives: 1.) define the influence of the concepts mala in se and mera prohibita to the classification of tatbestanb and differentiation between justice criminal law and secondary criminal law and understand the economic criminal law; 2.) observe the influence that the change of paradigms cause to the understanding of the ban error theory among the economic crimes. Concluded by the need to change the beacons of analysis on ban error, setting out new perspectives in focus of the economic criminal law, highlighting the role played by the consciousness of wrongfulness.

\section{Keywords}

Economic Criminal Law. Delicta In Se e Delicta Mera Prohibita. Ban Error.

\section{INTRODUÇÃO}

Quando o legislador se vale de critérios de necessidade/utilidade para a construção das figuras típicas, na verdade o elemento fundamental da proibição é o formal. Não se pode concluir que os comportamentos proibidos gozem de um conceito de desvalor coletivo, mas apenas que são necessários ou úteis para regular certos ramos ou áreas do funcionamento do corpo social.

Não restam dúvidas de que a dogmática penal tradicional foi construída a partir de um paradigma liberal que influenciou sobremodo o direito penal (e também foi por ele influenciado). Aquele arcabouço teórico foi o substrato sobre o qual foram forjados os institutos que integram o conceito analítico de crime. Igualmente, os bens jurídicos eleitos pelo legislador para estarem sob o manto da proteção penal diziam respeito ao sujeito individualmente considerado, sendo apenas recentemente reconhecidos aqueloutros 
com nítida feição supraindividual ou de pertença à humanidade como um todo.

Nesta senda, quanto ao conceito material de crime, reforça-se a validade dos paradigmas liberais, não superados pela crise pósmoderna, ao mesmo tempo em que cresce a tensão da criação de tipos com base no critério da utilidade. Assim, distinguem-se os delitos propriamente ditos (Delicta In Se) e os crimes que constituem meras proibições formais (Delicta Mere Prohibita), voltados à regulação e ao funcionamento de certos setores da atividade econômica.

Ocorre que, em sua sanha legiferante, o legislador, em certos momentos, revestiu sob o manto de proibição penal condutas desprovidas de substância ética e que apenas regulam o funcionamento de setores específicos da economia, ou melhor, subsistemas da sociedade.

Somente se verifica a reprovação do agente se este possuía, ao agir, consciência do caráter ilícito de sua conduta. Ocorre que a referida consciência não exige o conhecimento da norma legal roibitiva, mas demanda, por meio de um esforço de consciência, a partir de valores introjetados no processo de socialização, uma valoração paralela na esfera do leigo.

Ocorre que aqui reside o ponto central da discussão.

A proximidade das figuras típicas penais da ética social informará, em maior ou menor grau, a exigibilidade de conhecimento por parte do cidadão comum a respeito de uma determinada proibição formal.

Assim, a exegese quanto aos contornos do erro de proibição não é simplesmente alcançada a partir do corpo de normas sobre o qual se lança o estudo, isto é, se está a tratar do Direito Penal Econômico ou do direito penal nuclear. Ilação desta natureza apenas esconde o 
problema fulcral: a existência, no âmbito do Direito Penal Econômico, de uma seara penal ilegítima, inalcançável em tese e a priori pelo poder punitivo, mas alcançada de fato.

A ideia de que a proibição penal confere relevância ética ao crime não satisfaz, assim como os tipos criados pelo legislador não podem ser produto de meros atos de arbítrio, pois se demanda do sujeito, para conhecer a ilicitude de uma conduta, o reconhecimento de sua afronta ao substrato ético subjacente na comunidade. Entender de forma distinta representaria romper a legitimidade do direito penal e alçá-lo a mero arbítrio, imposição arbitrária do legislador para atender a programas de natureza política e/ou econômica não referendados pelos mecanismos de legitimação postos.

Ademais, nas novas fronteiras da expansão penal - muitas delas criadas justificadamente por imperativos de utilidade - destaca-se a impossibilidade de se definir a (in)ocorrência do erro de proibição com base no mero exame sobre o esforço de consciência do autor da conduta pretensamente culpável, sendo necessário lançar mãos de outros instrumentos para esta análise, notadamente o dever de informação.

Definidos tais contornos, impositivo tratamento distinto quanto ao erro de proibição: na hipótese de maior proximidade entre a conduta e a ética da comunidade jurídica, impõe-se ao sujeito, salvo raras exceções, o conhecimento da antijuridicidade de sua conduta; quando do hiato entre o crime e a matriz social definidora, afrouxamse os níveis de exigência direcionados ao agente e sua cognoscibilidade da ilicitude. 
De uma forma geral, os instrumentos de imputação penal e de culpabilidade defluem do Direito Penal nuclear e depois transbordam para o dito direito penal secundário. Parece intuitivo que as referidas estruturas dogmáticas, desenvolvidas sob o influxo iluminista e democrático, parecem adaptar-se muito melhor às espécies delituosas clássicas do que às espécies normativas integrantes do direito penal econômico. O mesmo acontece com o dolo e a consciência da antijuridicidade, sendo este dos mais relevantes, discutidos e difíceis temas da ciência penal'.

De fato, nos dias atuais, uma grande quantidade de delitos suscitam a análise da consciência da ilicitude, o que revela, no âmbito do direito comparado, nítida heterogeneidade nas soluções apresentadas pelos diferentes sistemas jurídicos, desde a absoluta irrelevância até a total relevância, passando por estados de relevância ou irrelevância relativa, do problema da consciência da ilicitude para a aferição da responsabilidade penal do agente ${ }^{3}$

De início, há de se asseverar que, ao tratar a questão da consciência da ilicitude, despontam dois vieses de análise: o formal e o material, os quais, entretanto, não podem ser confundidos.

Se é certo que a investigação do tema deve partir da análise da estrutura formal, com a discussão dos conceitos de consciência e

2 “O problema que aqui se considera ganhou desde há bastante tempo direito a ser tido como um dos mais importantes e debatidos, mas simultaneamente um dos mais complexos e obscuros, de todo o direito penal. A literatura que lhe vem sendo dedicada de há muito que se tornou inabarcável. DIAS, Jorge de Figueiredo. O Problema da Consciência da Ilicitude em Direito Penal. 5. ed. Coimbra: Coimbra Editora, 2000, pp. 1-2.

3 DIAS, Jorge de Figueiredo. O Problema da Consciência da Ilicitude em Direito Penal. 5. ed. Coimbra: Coimbra Editora, 2000, p. 2. 
ilicitude, não é possível tomar tais elementos como pressupostos indispensáveis da posição da questão. Não se deve comprometer o aspecto formal do problema como problemas posteriores do trato daquele, notadamente os conceitos de ação penal, tipo, dolo, posição do dolo.

Isto é, torna-se fundamental tratar a questão formal de maneira inicial, ao menos para delimitar que a definição de ilicitude pertence ao mundo do jurídico, ao passo que o conceito de consciência é colhido pelo jurídico da neurociência ${ }^{5}$ e introjetado no âmbito do direito.

4 Idem, p. 5.

5 Lecionam Christof Koch e Susan Greenfield: “a maneira como processos cerebrais se traduzem em consciência é um dos maiores desafios a ser resolvido pela ciência. Embora o método científico tenha conseguido delinear eventos que ocorreram imediatamente após o Big Bang e descobrir o maquinário bioquímico do cérebro, falha em explicar como a experiência subjetiva é criada. Como neurocientistas, ambos fizemos da resolução desse enigma a meta de nossa vida. Compartilhamos muitos pontos de vista, incluindo o importante reconhecimento de que não existe um único problema da consciência. Vários fenômenos devem ser explicados - particularmente a autoconsciência (a capacidade de examinar os próprios desejos e pensamentos), o conteúdo da consciência (de que realmente se está consciente a qualquer momento) e como processos cerebrais se relacionam à consciência ou à não-consciência. Então, por onde começa a solução? Os neurocientistas ainda não compreendem o suficiente sobre o funcionamento interno do cérebro para dizer exatamente como a consciência emerge da atividade química e elétrica dos neurônios. Assim, o primeiro passo é determinar os melhores correlatos neuronais da consciência (CNC) - a atividade cerebral que corresponde a experiências conscientes específicas. Quando você se dá conta de que está vendo um cachorro, o que aconteceu com quais neurônios do seu cérebro? Quando um sentimento de tristeza se apossa de você, o que aconteceu em seu cérebro? Estamos ambos tentando encontrar a contrapartida correlata de cada experiência consciente que uma pessoa possa ter. Disponível em 
Se é possível tomar a consciência da antijuridicidade como questão de culpa (em sentido lato, a abranger também o dolo), ilicitude, tipo e ação, não se pode considerar que o problema da consciência da ilicitude se desvenda a partir da mera definição daqueles institutos, mas, antes, exige uma problematização própria ${ }^{6}$.

De fato, a conceituação de institutos correlacionados à consciência da ilicitude, malgrado seja etapa necessária para melhor compreensão da problemática, mostra-se insuficiente para desvendar todos os aspectos da questão em estudo.

Por outro lado, também não é possível restringir o problema da consciência da ilicitude a uma questão puramente dogmática ${ }^{7}$, aqui entendida no sentido que lhe empresta Cerezo Mir, qual seja:

“[...] la dogmática del Derecho penal tiene la tarea de conocer el sentido de los preceptos jurídicos-penales positivos y desenvolver su contenido de modo sistemático. Puede decir-se que la tarea de la dogmática del Derecho penal es la interpretación del Derecho penal positivo, si el término interpretación es utilizado en su acepción más amplia, que incluye la elaboración del sistema. El término dogmática se deriva de la palabra dogma porque para el intérprete los preceptos de

http://www2.uol.com.br/sciam/reportagens/como_a_consciencia_se_manifesta_ .html. Acesso em 13/05/15.

6 DIAS, Jorge de Figueiredo. O Problema da Consciência da Ilicitude em Direito Penal. 5. ed. Coimbra: Coimbra Editora, 2000, p. 7.

7 Aqui entendida, numa concepção positivista-racionalista, como a ciência que tem por único objeto as normas legais do ordenamento jurídico e busca uma sistematização fechada extraída das referidas regras. 
Derecho positivo son como un dogma al que tiene que atenerse necessariamente" ${ }^{8}$.

Mais especificamente, no âmbito do direito penal econômico, a grande maioria das figuras penais constituem proibições de natureza formal, sem conteúdo ético relevante. Cite-se, a título de exemplo, o artigo 69, da Lei n. 8.078/90 (Código de Defesa do Consumidor)

Em realidade, parece intuitivo que o conhecimento da norma penal exemplificada não está ao alcance dos cidadãos em geral pelo simples processo de socialização secundária, qual seja, pela obtenção de conhecimentos e de funções direta ou indiretamente calcadas na divisão do trabalho ${ }^{10}$.

Ao cidadão ordinário, não exercente de funções diretamente afeitas à publicidade ou à prestação de serviços ou produtos ao consumidor parece pouco crível adquirir a consciência do sentido da

8 CEREZO MIR, Jose. Derecho penal. Parte General. Buenos Aires: B de f, 2008, p. 60. Tradução livre: "a dogmática do Direito penal tem a tarefa de conhecer o sentido dos preceitos jurídico-penais positivos e desenvolver seu conteúdo de modo sistemático. Pode-se dizer que a tarefa da dogmática do Direito Penal é a interpretação do Direito penal positivo, se o termo interpretação é utilizado em sua acepção mais ampla, que inclui a elaboração do sistema. O termo dogmática deriva da palavra dogma porque para o intérprete os preceitos de Direito positivo são como um dogma a que te que necessariamente se ater".

9 Art. 69. Deixar de organizar dados fáticos, técnicos e científicos que dão base à publicidade:

Pena Detenção de um a seis meses ou multa.

10 SETTON, Maria da Graça Jacinto. A particularidade do processo de socialização contemporâneo. Disponível em http://www.scielo.br/scielo.php?pid=S0103$\underline{20702005000200015 \& s c r i p t=s c i ~ a r t t e x t}$. Acesso em 16/05/2015. 
proibição acima exposta, senão pela via do conhecimento formal da norma legal proibitiva.

Ora, se o desvalor não resulta do sentido intrínseco da conduta, mas é a ela impregnado como atributo do exercício legislativo, qualquer esforço de consciência resulta eficaz, pois o saber da antijuridicidade não foi transmitido pela vivência comunitária.

Assim, admitir uma teoria do erro de proibição homogênea e com idênticos resultados para crimes em si e crimes de mera proibição significa mascarar o que há de mais relevante e fundamental a embasar a sua ideia, qual seja, a noção de culpabilidade. Entendida como reprovação pessoal do sujeito que agiu de forma antijurídica, vincula um juízo de valor que se volta para o sujeito individualmente considerado, com suas próprias características e conhecimentos, assim como saberes próprios angariados no curso de sua vivência comunitária.

$\mathrm{Na}$ realidade, o conhecimento da lei vigente, não só da lei penal, é uma presunção indispensável para a manutenção da higidez do ordenamento jurídico ${ }^{11}$. É presunção porque o sistema de publicidade utilizado para dar conhecimento às normas criadas não atinge, de fato, todos os cidadãos. Excluídos os casos mais claros dos iletrados, mesmo as pessoas que possuem razoável formação acadêmica não se prestam, de ordinário, à leitura diária e compilação de diários

11 Para Córdoba Roda, a respeito da natureza jurídica da inescusabilidade do conhecimento da lei, a doutrina indica três critérios distintos: presunção, expressão do caráter obrigatório da lei penal; exigência de caráter político, social ou processual. RODA, Juán Córdoba. El conocimiento de la antijuridicidad en la teoría del delito. Barcelona: Bosch Casa Editorial, 1962, p. 60. 
oficias. E mais, é também indispensável sob pena de o sistema jurídico ver-se esvaído de seu caráter cogente e obrigatório.

Em que pese a proximidade e a afinidade entre os temas, não se confundem os problemas da irrelevância do desconhecimento da lei penal e da irrelevância do erro de direito, salvo se se proceder uma aproximação rasa e acrítica ${ }^{12}$.

Em primeiro plano, a irrelevância do não conhecimento da lei não é exclusividade do direito penal, mas máxima apregoada indistintamente nos diferentes ramos jurídicos. Ademais, o conceito de erro de direito não é sinônimo de erro sobre ou a respeito da lei, sendo o primeiro, por certo, muito mais amplo e abrangente que o segundo.

Com efeito, a aceitação da absoluta identidade entre as questões somente foi levada a cabo em momentos históricos nos quais o pensamento jurídico foi conduzido pelo dogma do positivismo legalista, na medida em que se aceitava a identificação do direito com a lei ${ }^{13}$.

O primeiro fundamento a embasar o princípio da irrelevância do desconhecimento da lei penal reside na presunção de seu conhecimento. A presunção pode se estabelecer, a princípio, com mero viés processual, atrelado ao instituto da prova, mas em geral apresenta-se com real natureza material ou substancial ${ }^{14}$.

Do ponto de vista processual, a presunção pode se apresentar como absoluta ou relativa. Na primeira, inadmite prova em contrário,

12 DIAS, Jorge de Figueiredo. O Problema da Consciência da Ilicitude em Direito Penal. 5. ed. Coimbra: Coimbra Editora, 2000, p. 53.

13 Idem, p. 54.

14 Idem, p. 55. 
ou seja, ainda que seja possível provar, na hipótese concreta, o efetivo desconhecimento, tal comprovação não possui qualquer relevância. Ao revés, a presunção relativa é aquela que admite prova em contrário, ou seja, a comprovação, pelos meios de prova existentes e válidos em direito, que o fato sobre o qual se discute ocorreu ou não.

Admitir a absoluta irrelevância do desconhecimento da lei como uma regra de direito adjetivo que traduz uma presunção absoluta de conhecimento da norma penal representa uma contradição com outros elementos do sistema processual que admitem a validade de presunções probatórias ${ }^{15}$.

De fato, mesmo no direito penal, admitem-se algumas presunções, sendo a mais relevante a presunção de inocência ou princípio de não-culpabilidade, com envergadura constitucional (CF, art. 5o, LVII ${ }^{16}$ ).

Por outro lado, a consideração do referido princípio como uma norma de direito material, com viés de delimitação, à descortinação dos problemas efetivos da culpabilidade e do erro, não traz maiores luzes à solução da problemática ${ }^{17}$.

15 Idem, p. 55.

16 Art. 5o Todos são iguais perante a lei, sem distinção de qualquer natureza, garantindo-se aos brasileiros e aos estrangeiros residentes no País a inviolabilidade do direito à vida, à liberdade, à igualdade, à segurança e à propriedade, nos termos seguintes:

(...)

LVII - ninguém será considerado culpado até o trânsito em julgado de sentença penal condenatória.

17 DIAS, Jorge de Figueiredo. O Problema da Consciência da Ilicitude em Direito Penal. 5. ed. Coimbra: Coimbra Editora, 2000, p. 56. 
Parece intuitivo que, no bojo de um direito penal de culpabilidade e de raiz iluminista, seria inadmissível que o referido adágio encerrasse uma presunção absoluta e desprovida de limitações.

Ocorre que não são admitidas hipóteses de presunção de culpabilidade, de modo que não se pode necessariamente inferir do desconhecimento da norma um comportamento culposo ${ }^{18}$.

Em outras palavras, o princípio encerra uma obrigação geral de conhecimento das normas jurídicas e, por conseguinte, a responsabilização individual pelo descumprimento da obrigação. Assim sendo, está diretamente conectado, no plano teórico, com a concreta reprovação do agente pelo seu comportamento; no plano prático, oferece balizas para a decisão de casos reais. Com esta roupagem, o princípio se despe de caráter abstrato e absoluto e acaba condicionado pela real possibilidade de o agente conhecer a norma, isto é, cumprir a obrigação ${ }^{19}$.

É, de fato, esta real possibilidade de o agente conhecer a norma - e por consequência, orientar-se de acordo com o seu sentido - que constitui o ponto nevrálgico da presente discussão.

Como assevera Jorge de Figueiredo Dias ao tratar sobre a irrelevância do desconhecimento da lei, "um princípio unicamente atinente aos fundamentos da validade do direito (ou da lei) se transformou, indevidamente, em princípio normativo para a culpa e para a falta de consciência da antijuridicidade ${ }^{20 "}$.

18 RODA, Juán Córdoba. El conocimiento de la antijuridicidad en la teoría del delito. Barcelona: Bosch Casa Editorial, 1962, p. 59.

19 DIAS, Jorge de Figueiredo. O Problema da Consciência da Ilicitude em Direito Penal. 5. ed. Coimbra: Coimbra Editora, 2000, p. 58.

20 Idem, p. 64. 
Seria assim, um mero reforço obrigacional de observância da norma, desprovido de ulterior função e validade e absolutamente desconectado com a noção de reprovação pessoal do sujeito por ter agido de forma contrária do Direito (aqui entendido não só como lei!).

Foi o pensamento alemão do século XX que impulsionou a mudança de tratamento conferido à distinção do erro, que haveria de se ligar à sua orientação (objeto sobre o qual versa ou fundamento), e não à sua ontologia ou espécie intrínseca ${ }^{21 .}$

Surgem, deste feita, o erro de tipo e o erro de proibição em superação aos vetustos erro de fato e erro de direito.

De fato, esta conclusão pode ser inferida da própria redação do $\S 59$, I do Código Penal alemão ${ }^{22}$, porque, ao se referir ao tipo, não está a tratar de circunstância de fato, as circunstâncias de fato que se referem ao tipo. Assim, não se estava a discutir a dicotomia erro de fato

21 DIAS, Jorge de Figueiredo. O Problema da Consciência da Ilicitude em Direito Penal. 5. ed. Coimbra: Coimbra Editora, 2000, p. 66.

$22 \mathcal{S} 59$. Presupuestos de la amonestación con reserva de penal (1) Si alguien incurre en pena de multa hasta 180 días de importes diarios, entonces el tribunal puede amonestarle accesoriamente al fallo condenatorio, determinar la pena y reservar la condena para esa pena, cuando:

1. sea de esperar que el autor se abstenga en el futuro de cometer hechos punibles aun sin condena a pena.

2. una valoración en conjunto del hecho y de la personalidad del autor demuestran especiales circunstancias según las cuales es procedente que a él se le puede eximir de la condena a pena; $y$,

3. La defensa del ordenamiento jurídico no exija la condena a pena.

$E I \mathcal{S} 56$ inciso primero segunda frase rige en lo correspondiente. Disponível em http://www.juareztavares.com/textos/leis/cp_de_es.pdf. Acesso em 17/05/2015. 
e erro de direito ${ }^{23}$, mas a contraposição do erro sobre o comportamento típico, nos seus elementos fáticos e jurídicos, ao erro sobre a natureza proibida do tipo perpetrado ${ }^{24}$.

Isto é, composto o tipo por uma série de elementos de diversas naturezas, o erro sobre um ou vários daquele representa um erro de tipo, embora não necessariamente um erro sobre uma circunstância fática. Por outro lado, o tipo é impregnado pela nota da antijuridicidade, da proibição conferida pelo ordenamento jurídico, de forma que o erro sobre esta incidente importa em erro de proibição ${ }^{25}$.

A irrelevância do erro de direito em razão de sua indesculpabilidade foi desenvolvida na doutrina quando se tratava dos chamados crimina naturaliter proba, isto é, quando o erro versava sobre regras de moralidade ou religião, em outras palavras, sobre

23 Afirma Assis Toledo: “Os que incorrem nessas falhas de conceituação ou não desejam contribuir para o desenvolvimento da moderna teoria do erro, tratandoa de forma superficial a vol d'oiseau, ou não conseguiram ainda desvincular-se de dogmas e aporias do passado". TOLEDO, Francisco de Assis. Erro de Tipo e Erro de Proibição no Projeto de Reforma Penal. RT, 578/295

24 DIAS, Jorge de Figueiredo. O Problema da Consciência da Ilicitude em Direito Penal. 5. ed. Coimbra: Coimbra Editora, 2000, p. 67.

25 Erro sobre a ilicitude do fato

Art. 21 - O desconhecimento da lei é inescusável. O erro sobre a ilicitude do fato, se inevitável, isenta de pena; se evitável, poderá diminuí-la de um sexto a um terço. (Redação dada pela Lei no 7.209, de 11.7.1984)

Parágrafo único - Considera-se evitável o erro se o agente atua ou se omite sem a consciência da ilicitude do fato, quando lhe era possível, nas circunstâncias, ter ou atingir essa consciência. (Redação dada pela Lei no 7.209, de 11.7.1984) 
direito natural, as quais residiriam na consciência dos homens, por serem de fácil conhecimento a todos ${ }^{26}$.

Desta forma, bastaria ao sujeito uma mera reflexão ou esforço de consciência para alcançar o conhecimento da antijuridicidade por ele já introjetado pelo conhecimento auferido pela vivência comunitária, independentemente da natureza formal da proibição.

Por consequência, a falta de conhecimento da ilicitude seria irrelevante, posto indesculpável, quando das normas penais de incriminação apresentassem nítido conteúdo ético, informado por concepções religiosas ou morais. Assim, os comportamentos vedados estariam estampadas nas consciências dos indivíduos, em suas consciências éticas ${ }^{27}$.

Ora, desta forma, não conhecer a ilicitude, podendo fazê-lo por esforço e conhecimento próprio representaria nítida postura de hostilidade ou menoscabo ao direito.

Afirma Dias:

“[...] se - e é nesta precisa medida que a tese aqui nos interessa - a norma de comportamento está inapagavelmente inscrita na consciência-ética de cada um e os conteúdos jurídico-penalmente ilícitos se apresentam sem mais como evidentes à consciênciaintencional do agente, também uma verdadeira falta de consciência da ilicitude ou há-de ser complemente impossível, ou, quando excepcionalmente se dê, há-de ser imediatamente censurável e culposa, seja qual for o

26 DIAS, Jorge de Figueiredo. O Problema da Consciência da Ilicitude em Direito Penal. 5. ed. Coimbra: Coimbra Editora, 2000, p. 105.

27 Idem, p. 105. 
conteúdo material que à culpa jurídico-penal se impute, i. é, como quer que ela materialmente se conceba ${ }^{28}$.

Em sua Ética a Nicômaco, Aristóteles distinguiu entre o erro sobre as regras gerais da moralidade ou universalia, quais seja, aquelas normas que deveriam ser conhecidas por todos, na medida em que eram de fácil conhecimento, o qual seria irrelevante, posto indesculpável, do erro sobre os singularia, releváveis e desculpáveis, assim como separou o direito natural e o direito legal ou positivo ${ }^{29}$.

A questão do recurso ao direito natural é bastante tormentosa, muito embora o raciocínio aristotélico apresente a notável genialidade de admitir que o tratamento do erro não admite uma solução única, mas depende da natureza dos delitos sobre o qual incide. A desculpabilidade ou indesculpabilidade do erro está relacionada diretamente ao conteúdo material das proibições criminais.

Desde os idos de 1945, principalmente, retomou-se o movimento antipositivista, com o viés de retorno ao um direito natural. Ademais, recentemente também desenvolveu-se uma busca de eticização do direito penal, a fim de que o legislador se limitasse a intervir, na criação de tipos penais, nas hipóteses das mais relevantes lesões de bens jurídicos comunitários, referidos ao livre desenvolvimento da personalidade moral do ser humano, ocorrendo de novo a associação entre o cerne das proibições jurídico-penais e os preceitos primários do jusnaturalismo idealista. Deste retorno ao direito natural reafirma-se a tese da impossibilidade de erros não

28 Idem, p. 105.

29 ARISTÓTELES. Ética a Nicômaco. Tradução de Leonel Valhandro e Gerd Bornheim da versão inglesa de W. D. Ross. v. 4. In: Pensadores. São Paulo: Nova Cultural, 1973, p. 118. 
culposos a respeito do direito natural e da irrelevância da falta de consciência da antijuridicidade ${ }^{30}$.

Ocorre que esta dita eticização, embora com respaldo no direito penal de justiça, peca em seus efeitos no que atine aos tipos penais de mera proibição. Diferentemente deve ser a compreensão da falta de consciência da antijuridicidade quanto aos crimes artificiais.

Como assevera Muñoz Conde, quando se trata dos delitos artificiais, sobretudo os crimes fiscais, nos quais a atuação negligente do agente que descumpre, por exemplo, seus deveres tributários e atua com erro vencível, está a merecer uma maior compreensão, que pode levar mesmo à impunidade de seu comportamento culposo. Malgrado esta conclusão de direito penal, não se esquivará das sanções de natureza administrativa ${ }^{31}$.

Em realidade, o dito retorno ao direito natural reforça a crença numa validade e fundamentação do direito para além da mera decisão legislativa do Estado. Afirma ainda a descoberta de princípios aplicáveis a situações novas e para as quais os princípios tradicionais já conhecidos não oferecem alternativas viáveis de decisão ${ }^{32}$.

Entretanto, para fins de direito penal, apenas após a previsão legal é que a proibição passa a ser criminosa. Se restar plasmado na norma um conteúdo ético socialmente reconhecido, está-se diante do direito penal nuclear.

30 ARISTÓTELES. Ética a Nicômaco. Tradução de Leonel Valhandro e Gerd Bornheim da versão inglesa de W. D. Ross. v. 4. In: Pensadores. São Paulo: Nova Cultural, 1973, p. 119.

31 MUÑOZ CONDE, Francisco. El error en Derecho Penal. Buenos Aires: Rubinzal-Culzoni, 2003, p. 76.

32 DIAS, Jorge de Figueiredo. O Problema da Consciência da Ilicitude em Direito

Penal. 5. ed. Coimbra: Coimbra Editora, 2000, p. 120. 
Foi com base neste núcleo penal que, no curso da história se apresenta como standard de referência, é que se consolidaram as teorias da teoria geral do delito. Não por acaso, para Munõz Conde, o quase consenso em torno da relevância do erro naqueles tipos que tradicionalmente perfazem o núcleo do direito penal, quais sejam, homicídio, lesões corporais, roubos etc ${ }^{33}$.

Por outro lado, o desenvolvimento da doutrina do direito natural deixou de considerá-lo como um conjunto de princípios abstratos e gerais aplicáveis, de forma padronizada, a qualquer hipótese concreta para ele mesmo introduzir-se e realizar-se na situação analisada. Ora, o agir que respeita ou desrespeita o direito natural não é mera implementação prática de uma norma abstrata e geral, mas, principalmente, uma opção realizada por uma pessoa entre o jurídico e o antijurídico em uma dada situação. Por consequência, a problemática da consciência da ilicitude não é sinônimo da questão do conhecimento ou desconhecimento da lei que indica a decisão correta ao caso vertente. Ainda que o referido princípio se aplique à situação, uma coisa é o próprio conhecimento da norma, outra é a consciência da licitude de uma decisão específica ${ }^{34}$.

Diferentemente ocorre quando o comportamento é proibido por ser ilícito, na medida em que não se tem como norma originária um imperativo, mas uma norma que atribui aos comportamentos o valor de injusto ou antissocial. Neste caso, para um entendimento calcado nesta forma originária da norma, torna-se despicienda uma consciência da ilicitude. Desta feita, haveria uma necessária associação

33 MUÑOZ CONDE, Francisco. El error en Derecho Penal. Buenos Aires: Rubinzal-Culzoni, 2003, p. 90.

34 DIAS, Jorge de Figueiredo. O Problema da Consciência da Ilicitude em Direito

Penal. 5. ed. Coimbra: Coimbra Editora, 2000, p. 123 
entre relevância do conhecimento da antijuridicidade e imperativismo e irrelevância deste conhecer e não-imperativismo ${ }^{35}$.

De fato, com base em um conceito material de culpabilidade, faz-se indispensável, para a sanção penal, a consciência da ilicitude do agente, pouco importando a problemática da forma originária da norma.

Contra esta tese aduza-se que o ilícito se situa antes da vedação, de modo que a consciência da ilicitude se mostra sempre relevante. A questão não estaria no imperativismo ou não-imperativismo, mas na necessidade de culpabilidade como pressuposto necessário da punição do agente ${ }^{36}$.

De fato, a culpabilidade é pressuposto da punibilidade e, pouco importando a dicção da norma penal, seja valoração, seja determinação, deve se fazer presente como pressuposto da punibilidade.

A controvérsia torna-se ainda mais reduzida quando se vislumbra que os momentos de valoração e determinação são sempre prévios em qualquer ordem jurídica e de qualquer norma jurídica. A distinção reside na tese dos imperativisitas de que toda norma, para ser jurídica, precisa ser imperativa, ao passo que para os nãoimperativistas, a norma jurídica pode revestir-se de pura norma de valoração ${ }^{37}$.

Entretanto, para fins de aferição da relevância da consciência da ilicitude, a natureza mutável ou imutável da culpabilidade pouco

35 Por todos, Radbruch. Fisolofia do Direito I, 127 e ss.

36 DIAS, Jorge de Figueiredo. O Problema da Consciência da Ilicitude em Direito

Penal. 5. ed. Coimbra: Coimbra Editora, 2000, p. 127.

37 Idem, p. 129. 
determina se não verificada a atribuição de uma concepção psicológica $^{38}$ ou normativa à culpabilidade.

Pela primeira concepção, o cerne da questão reside na vinculação dolosa ou culposa ao tipo objetivo de ilícito, de modo que nada influencia a falta de consciência da antijuridicidade. Pela concepção normativa, necessário se fazer referência à natureza ilícita da conduta, a qual precisa ou pode ser apreendida ou valorada pelo sujeito, a demandar uma consciência (atual ou potencial) da ilicitude ${ }^{39}$. Enquanto a concepção psicológica centra-se no vínculo de mesma natureza entre o autor e o tipo objetivo, traduzido em culpa ou dolo, a normativa agrega elementos que a qualificam e demanda uma valoração do sujeito da qualidade ilícita de seu atuar. A segunda representa uma evolução na teoria do crime e assenta-se em fundamentos mais robustos do que aqueles que sustentam a primeira.

Na concepção normativa da culpabilidade, inexiste culpa sem censurabilidade, mesmo que haja o vínculo psicológico entre o autor e o tipo objetivo. Daí porque a culpabilidade exige uma valoração do

38 Assim, para os adeptos da concepção psicológica, os elementos do delito separam-se em uma parte objetiva e outra subjetiva. Na primeira colocam-se o tipo e a ilicitude. O tipo é entendido como a descrição externa da ação e considerado valorativamente neutro (...). Na segunda, reside a culpabilidade, conceituada como vínculo psicológico. Para estes mesmos autores, a ação é conceituada como a 'causação voluntária de uma modificação no mundo exterior'. A vontade é considerada mero 'impulso inicial que desloca a inércia do comportamento', e à caracterização da voluntariedade da ação basta que não tenha havido sobre o agente, no momento em que a praticou, coação mecânica ou psicofísica. BRODT, Luís Augusto Sanzo. Da Consciência da Ilicitude no Direito Penal Brasileiro. 1. ed. Belo Horizonte: Del Rey, 1995, pp. 35-36.

39 DIAS, Jorge de Figueiredo. O Problema da Consciência da Ilicitude em Direito Penal. 5. ed. Coimbra: Coimbra Editora, 2000, p. 140. 
julgador sobre o substrato psicológico do agente e o elemento que importaria na censurabilidade é a consciência da ilicitude. Entretanto, ela também pode se mostrar relevante num contexto de acepção psicológica da culpabilidade, na medida em que os atos de conhecimento e de valoração são atos psíquicos. Assim, o que se exige na concepção normativa da culpabilidade é a consciência potencial da ilicitude que não significa equivalência com processos psicológicos ${ }^{40}$.

Em realidade, um mero substrato de natureza psicológica não é suficiente para definir a responsabilidade do sujeito pelo fato, posto necessário um elemento normativo, qual seja, a exigibilidade de conduta adequada ao dever. Esta, por seu turno, independe de qualquer consciência atual ou potencial da antijuridicidade, sendo ambas elementos autônomos ${ }^{41}$.

É também assim previsto no ordenamento jurídico brasileiro, nos termos do 22, do Código Penal ${ }^{42}$.

À problemática da consciência da ilicitude e da sua repercussão ligam-se umbilicalmente as teorias do dolo e da culpabilidade.

Para os defensores da teoria do dolo, só haverá conduta dolosa quando o sujeito age ciente do conjunto de elementos fáticos que conformam o seu atuar, acrescido do significado jurídico da conduta no que toca à ilicitude, ao menos por meio de uma valoração paralela

40 DIAS, Jorge de Figueiredo. O Problema da Consciência da Ilicitude em Direito Penal. 5. ed. Coimbra: Coimbra Editora, 2000, p. 141-142.

41 Idem, p. 144.

42 Coação irresistível e obediência hierárquica (Redação dada pela Lei no 7.209, de 11.7.1984)

Art. 22 - Se o fato é cometido sob coação irresistível ou em estrita obediência a ordem, não manifestamente ilegal, de superior hierárquico, só é punível o autor da coação ou da ordem.(Redação dada pela Lei no 7.209, de 11.7.1984) 
na esfera do profano ${ }^{43}$. Desta forma, a ausência de consciência atual da antijuridicidade possui o mesmo resultado da falta de consciência dos elementos fáticos. A falta daquela consciência sempre se mostra relevante por excluir o dolo, ressalvada a possibilidade de sanção a título de culpa, se houver a previsão específica ${ }^{44}$.

Por outro lado, as teorias da culpabilidade entendem a consciência da ilicitude como elemento da culpabilidade, mas não a concebem na forma de consciência atual, integrante do dolo, que se resume a conhecimento e vontade da realização do tipo. Ao revés, temse uma cognoscibilidade ou conhecimento potencial da antijuridicidade, cuja ausência pode excluir a culpabilidade, mas subsiste o dolo. Ou seja, o agente continua a ser punido a título de dolo, mas a sanção pode se abrandada em razão do erro e da menor reprovação da conduta ${ }^{45}$.

Vê-se, portanto, que há uma nítida distinção entre as teorias. Para os adeptos das teorias do dolo, neste se insere a consciência atual da antijuridicade ${ }^{46}$, cuja ausência importa exclusão do dolo e apenas

43 MEZGER, Edmund. Tratado de Derecho Penal. T. II. Madri: Revista de Derecho Privado, 1935, pp. 139 e ss.

44 DIAS, Jorge de Figueiredo Dias. O Problema da Consciência da Ilicitude em Direito Penal. 5. ed. Coimbra: Coimbra Editora, 2000, p. 146.

45 DIAS, Jorge de Figueiredo. O Problema da Consciência da Ilicitude em Direito Penal. 5. ed. Coimbra: Coimbra Editora, 2000, p. 147.

46 Por todos, Luzón Peña: “... o conceito de dolo que aqui se mantém é: conhecimento e vontade de realizar todos os elementos objetivos do tipo total de injusto, tanto os de sua parte positiva ou tipo indiciário, como os de sua parte negativa do tipo, é dizer, a ausência dos elementos de causas de atipicidade e causas de justificação; uns e outros são os pressupostos da antijuridicidade ou proibição penal. Em contrapartida, o dolo não requer conhecimento ou consciência da própria antijuridicidade ou proibição (nem geral nem penal) da 
punição a título de culpa, se verificada imprudência, negligência ou imperícia e houver previsão específica da figura culposa. Sob um outro enfoque, as teorias da culpabilidade restinguem o dolo aos elementos cognitivo e volitivo, restando localizada a consciência da antijuridicidade - potencial - como elemento da culpabilidade, de modo que a sua ausência em nada interfere na qualificação da conduta como dolosa. Entretanto, se inexiste a cognoscibilidade da ilicitude, a culpabilidade restará excluída ou diminuída.

Ressalte-se que, do sintético cotejo apresentados, que as teorias do dolo e da culpabilidade destoam, de logo, quanto à configuração do dolo.

Segundo Jorge de Figueiredo Dias, o ponto nevrálgico está na localização do dolo no sistema jurídico-penal. As teorias do dolo tomam-no como elemento constitutivo da culpabilidade, donde se conclui que a atual consciência da antijuridicidade integra o dolo. As teorias da culpabilidade, ao revés, entendem o dolo como elementos de constituição da ação e do tipo subjetivo, portanto distinto e distante da consciência da antijuridicidade, a qual, por sua vez, é parte do juízo de culpabilidade ${ }^{47}$.

A distinção apresentada não é meramente topográfica. Isto é, não se trata apenas de identificar a consciência da antijuricidade como elemento do dolo ou da culpabilidade. Fundamentalmente cumpre

conduta” LUZÓN-PEÑA, Diogo Manuel. Curso de Derecho Penal: Parte General I. Madrid: Universitas, 1996, p. 405.

47 DIAS, Jorge de Figueiredo Dias. O Problema da Consciência da Ilicitude em Direito Penal. 5. ed. Coimbra: Coimbra Editora, 2000, p. 149. 
assumir posição entre um dolo normativo (dolus malus ${ }^{48}$ ) e um dolo natural, consoante apregoado pelos finalistas.

Evidentemente, além desta distinção fulcral, existem outras notas destoantes entre as teorias apresentadas, especialmente no que atine à controvérsia sobre ser ou não a antijuridicidade um elemento do tipo. Admitindo que o seja, conquanto o dolo se refira a todos os elementos que constituem a figura típica, forçoso concluir pela consciência da antijuridicidade como sua integrante. Assim, ainda seria desnecessário distinguir entre erro sobre os elementos de fato do tipo e erro sobre a ilicitude, aplicando-se a ambos o mesmo regime. Neste cenário, parece prevalecer a solução preconizada pelas teorias do dolo $^{49}$.

Ocorre que, mesmo a considerar a ilicitude um elemento do tipo - conclusão com a qual não comungamos - pode-se tê-lo como elemento especial quando se trata da questão do erro. $\mathrm{O}$ fato de um

48 Assevera Mir Puig que "a nosso juízo, o dolo completo exige a 'consciência da antijuridicidade', porém é conveniente distinguir três graus ou níveis de dolo: o dolo típico, que só exige o conhecimento e vontade do fato típico, o dolo referido ao fato típico sem os pressupostos típicos de uma causa de justificação, e o dolo completo, que, ademais, supõe o conhecimento da antijuridicidade (dolus malus). Ao estudar o tipo doloso importa unicamente o primeiro nível de dolo típico, que corresponde ao conceito de dolo natural usado pelo finalismo. Nesse contexto, e por motivos de brevidade, em princípio, utilizaremos o termo dolo no sentido de dolo típico. Quando nos ocuparmos das causas de justificação, veremos que então o dolo exige o segundo nível de dolo correspondente. Finalmente, o dolo completo será necessário para a imputação pessoal da antijuridicidade penal.” MIR PUIG, Santiago. Derecho Penal. Parte General. 9. Ed. Buenos Aires: B DE F, 2004, p. 240.

49 DIAS, Jorge de Figueiredo. O Problema da Consciência da Ilicitude em Direito Penal. 5. ed. Coimbra: Coimbra Editora, 2000, p. 150-151. 
certo elemento estar localizado no tipo não implica, de per si, que a sua não-representação importa inevitavelmente na exclusão do dolo. Pode-se tratar o erro sobre a ilicitude, inserta no tipo, de maneira distinta do erro que incide sobre outros elementos típicos ${ }^{50}$.

De toda sorte, as teorias mais modernas inclinam-se por negar a ilicitude como integrante do tipo. Em realidade, a ilicitude é o fundamento e o tipo a exprime de forma especializada. Assim, a ilicitude não é e nem poderia ser um elemento do tipo, mas um significado que abrange todos os elementos típicos ${ }^{51}$.

Parece intuitivo que a antijuridicidade é um complexo de significado que banha os elementos constitutivos do tipo de forma conjunta, de modo que não pode ser reduzida a um deles. E mais, sendo possíveis condutas típicas, mas não antijurídicas e, ainda, condutas antijurídicas, mas não típicas, não há como entender de forma diversa a relação entre o tipo e a ilicitude.

Assim, os vínculos entre tipo e ilicitude pouco ou nada dizem a respeito da localização e da fisionomia da consciência da ilicitude na estrutura do complexo jurídico-penal.

O cerne das teorias do dolo reside em atribuir ao dolo a qualidade de elemento constitutivo da culpabilidade e, desta forma, do juízo de valor que incide sobre a ação típica e antijurídica. Ademais, encontra no dolo um elemento intelectual integrado pelo conhecimento da figura típica e pela consciência da ilicitude, os quais projetam uma valoração sobre o injusto ${ }^{52}$.

50 DIAS, Jorge de Figueiredo. O Problema da Consciência da Ilicitude em Direito Penal. 5. ed. Coimbra: Coimbra Editora, 2000, p. 151-152.

51 Idem, p. 152.

52 Idem, p. 154-155. 
O entendimento de que o dolo é integrante da culpabilidade importa, para muitos, na conclusão de que se não esgota no conhecimento e vontade de realização de uma certa figura típica, de modo a se distanciar do protótipo de um dolo natural. Assim, seria necessário acrescentar à estrutura dolosa um elemento jurídiconormativo especial apto a torná-lo um dolo normativo ou dolus malus. Este elemento extra seria exatamente a consciência atual da antijuridicidade ${ }^{53}$.

Ocorre que esta linha de raciocínio não abrange a unanimidade dos doutrinadores penais.

Merecem destaque também as teorias limitadas do dolo que, apesar de conceberem o dolo como elemento da culpabilidade, não aceitam as soluções apontadas pelas teorias do dolo ditas estritas.

Mezger propôs uma construção teórica em que o dolo é composto da junção entre o dolo natural e a consciência atual da antijuridicidade. Ocorre que, quando a falta desta resulta de um especial traço da personalidade do sujeito (cegueira) ou de sua inimizade ao direito, não se afigura como óbice para aplicação ao agente de uma sanção por ato doloso. Em consequência, haveria uma culpabilidade e, portanto, censura, por condução de vida ${ }^{54}$.

Assim, mesmo quando não houvesse efetiva consciência do agir contrário ao direito, seria possível a punição do agente pela figura dolosa quando se verificasse sua atitude de repugnância aos conceitos de lícito e ilícito e, portanto, um defeito em sua formação.

53 Idem, p. 155.

54 DIAS, Jorge de Figueiredo. O Problema da Consciência da Ilicitude em Direito Penal. 5. ed. Coimbra: Coimbra Editora, 2000, p. 161. 
O núcleo agregador das teorias da culpabilidade reside em considerar o dolo como elemento do tipo e, portanto, da ação, em um contexto de dolo natural e ação final ${ }^{55}$. Assim, o dolo é a finalidade empregada na modulação e condução de um processo causal ${ }^{56}$. Por consequência, a culpabilidade e a ilicitude não influenciam na estrutura do dolo ${ }^{57}$.

Entretanto, apesar da existência de um âmago comum, existem profundas divergências nas teorias da culpabilidade que se centram em questões periféricas.

As sérias dissensões ligam-se ao tratamento do erro sobre os pressupostos de uma causa excludente da ilicitude, aqui também sendo possível divisar teorias da culpa estritas, a abranger aquele erro na

55 Em sentido, oposto Roxin: "Desde aproximadamente 1970 se vêm empreendendo esforços bastante discutidos no sentido de desenvolver um sistema jurídico-penal 'teleológico racional' ou 'funcional'. Os adeptos desta concepção estão de acordo - apesar de várias divergências quanto ao resto - na recusa às premissas sistemáticas do finalismo e em partir da idéia de que a construção sistemática jurídico-penal não deve orientar-se segundo dados prévios ontológicos (ação, causalidade, estruturas lógico-reais etc.), mas ser exclusivamente guiada por finalidades jurídico-penais." ROXIN, Claus.

Funcionalismo e Imputação Objetiva no Direito Penal. Trad. Luís Greco. Rio de Janeiro: Renovar, 2002, p. 204.

56 Juarez Tavares assevera que o sistema causal-naturalista "fazendo-se da causalidade objetiva e do liame subjetivo partes constitutivas essenciais do delito, dissocia-se sua análise, conseqüentemente, em dois estágios legais, de maneira que a primeira (causalidade) se encontra caracterizada na tipicidade e na antijuridicidade, e a última parte (vínculo psicológico) constitui a base da culpabilidade". TAVARES, Juarez. Teorias do delito (variações e tendências). São Paulo: Revista dos Tribunais, 1980, p. 20.

57 DIAS, Jorge de Figueiredo. O Problema da Consciência da Ilicitude em Direito Penal. 5. ed. Coimbra: Coimbra Editora, p. 163. 
seara do erro de proibição, e as teorias limitadas, para as quais se trata de um erro de tipo ${ }^{58}$.

O Código Penal brasileiro expressamente adotou a teoria limitada da culpabilidade, conforme se infere em sua Exposição de Motivos $^{59}$.

O dolo relevante do ponto de vista jurídico sempre abrange a vontade da ação final, mas não se resume a esta. Há ainda em seu bojo exigências de significado impostas pelo tipo ou exigências normativas suplementares. Assim, ao lado de um cerne imutável e ontológico da ação, residem produtos mutáveis e historicamente condicionados ${ }^{60}$.

De fato, as ditas exigências normativas suplementares podem ser desde o conhecimento de todos os elementos que integram a figura típica até a estrita ilicitude do fato, passando pelo conhecimento do sentido social, danosidade social ou imoralidade da conduta ${ }^{61 .}$

Notadamente no âmbito do direito penal econômico, face as peculiaridades de seus tipos, torna-se ainda mais relevante a análise

58 Idem, pp. 163-164.

59 É, todavia, no tratamento do erro que o princípio nullum crimen sine culpa vai aflorar com todo o vigor no direito legislado brasileiro. Com efeito, acolhe o Projeto, nos arts. 20 e 21, as duas formas básicas de erro construídas pela dogmática alemã: erro sobre elementos do tipo (Tatbestandsirrtum) e erro sobre a ilicitude do fato (Verbotsirrtum). Definiu-se a evitabilidade do erro em função da consciência potencial da ilicitude (parágrafo único do art. 21), mantendo-se no tocante às descriminantes putativas a tradição brasileira, que admite a forma culposa, em sintonia com a denominada "teoria limitada da culpabilidade". TOLEDO, Francisco de Assis. Culpabilidade e a problemática do erro jurídico penal. São Paulo: Revista dos Tribunais, 517/251, nov. 1978.

60 DIAS, Jorge de Figueiredo. O Problema da Consciência da Ilicitude em Direito Penal. 5. ed. Coimbra: Coimbra Editora, 2000, p. 167.

61 Idem, p. 70. 
destas exigências normativas que se aproximam, em face da ausência de conteúdo ético em muitas das incriminações, do conhecimento da ilicitude do fato.

Ocorre que esta construção de estruturas de imputação no bojo do direito penal secundário possui questionável legitimidade. Primeiramente porque é impossível transportar conceitos dogmáticos para ramos distintos do direito penal de uma maneira acrítica, tendo em vista que no direito penal de justiça os conceitos estão embasados a partir da consideração do agente como pessoa humana. Ademais, a realidade ética subjacente aos crimes do direito penal primário e do direito secundário são normalmente distintas ${ }^{62}$.

E mais:

“[...] a questão é tanto mais pertinente quanto em geral os crimes previstos no Código Penal têm a ver genericamente com aspectos essenciais da vida em sociedade, enquanto o Direito Penal secundário e o Direito de Mera Ordenação Social regulam apenas comportamentos, actividades ou setores específicos da vida social-económica que não correspondem ao funcionamento geral da vida social”33.

Em confronto com o ordenamento penal brasileiro, a lição acima colacionada, posto extremamente valiosa, demanda uma série de adaptações. Por primeiro, não se conhece a figura autônoma, inserida no âmbito penal, do direito de mera ordenação social. Ademais, não é possível estabelecer uma análise somente topográfica

62 PINTO, Frederico de Lacerda da Costa. Erro e Consciência da Ilicitude em Infrações contra o Mercado de Valores imobiliários. Direito Penal Económico e Europeu: Textos Doutrinários. v. III. Coimbra: Coimbra Editora, 2009, p. 662. 63 Idem, p. 662. 
das figuras delitivas e estabelecer que no Código Penal brasileiro são apenas tutelados bens jurídicos essenciais, posto estarem codificados tipos penais que apenas regulam determinado setor da atividade das figuras delitivas e estabelecer que no Código Penal brasileiro são apenas tutelados bens jurídicos essenciais, posto estarem codificados tipos penais que apenas regulam determinado setor da atividade econômica, a exemplo dos artigos 168-A, e 337- $\mathrm{A}^{64}$ do Estatuto repressivo pátrio.

64 Art. 337-A. Suprimir ou reduzir contribuição social previdenciária e qualquer acessório, mediante as seguintes condutas: (Incluído pela Lei no 9.983, de 2000) I - omitir de folha de pagamento da empresa ou de documento de informações previsto pela legislação previdenciária segurados empregado, empresário, trabalhador avulso ou trabalhador autônomo ou a este equiparado que lhe prestem serviços; (Incluído pela Lei no 9.983, de 2000)

II - deixar de lançar mensalmente nos títulos próprios da contabilidade da empresa as quantias descontadas dos segurados ou as devidas pelo empregador ou pelo tomador de serviços; (Incluído pela Lei no 9.983, de 2000) III - omitir, total ou parcialmente, receitas ou lucros auferidos, remunerações pagas ou creditadas e demais fatos geradores de contribuições sociais previdenciárias: (Incluído pela Lei no 9.983, de 2000)

Pena - reclusão, de 2 (dois) a 5 (cinco) anos, e multa. (Incluído pela Lei no 9.983, de 2000)

$\S 1$ 1o É extinta a punibilidade se o agente, espontaneamente, declara e confessa as contribuições, importâncias ou valores e presta as informações devidas à previdência social, na forma definida em lei ou regulamento, antes do início da ação fiscal. (Incluído pela Lei no 9.983, de 2000)

§ 2o É facultado ao juiz deixar de aplicar a pena ou aplicar somente a de multa se o agente for primário e de bons antecedentes, desde que: (Incluído pela Lei no 9.983, de 2000)

I - (VETADO) (Incluído pela Lei no 9.983, de 2000)

II - o valor das contribuições devidas, inclusive acessórios, seja igual ou inferior àquele estabelecido pela previdência social, administrativamente, como sendo o 
Por outra banda, há tipos penais que habitam a legislação extravagante, mas tutelam bens jurídicos essenciais à sociedade, a exemplo do artigo 54, da Lei n. ${ }^{\circ}$ 9.605/98 ${ }^{65}$.

mínimo para o ajuizamento de suas execuções fiscais. (Incluído pela Lei no 9.983, de 2000)

§ 3o Se o empregador não é pessoa jurídica e sua folha de pagamento mensal não ultrapassa $\mathrm{R} \$ 1.510,00$ (um mil, quinhentos e dez reais), o juiz poderá reduzir a pena de um terço até a metade ou aplicar apenas a de multa. (Incluído pela Lei no 9.983 , de 2000)

$\S 4 \mathrm{o} O$ valor a que se refere o parágrafo anterior será reajustado nas mesmas datas e nos mesmos índices do reajuste dos benefícios da previdência social. (Incluído pela Lei no 9.983, de 2000)

65 Art. 54. Causar poluição de qualquer natureza em níveis tais que resultem ou possam resultar em danos à saúde humana, ou que provoquem a mortandade de animais ou a destruição significativa da flora:

Pena - reclusão, de um a quatro anos, e multa.

$\S 1$ 을 o crime é culposo:

Pena - detenção, de seis meses a um ano, e multa.

$\S 2$ 2o Se o crime:

I - tornar uma área, urbana ou rural, imprópria para a ocupação humana;

II - causar poluição atmosférica que provoque a retirada, ainda que momentânea, dos habitantes das áreas afetadas, ou que cause danos diretos à saúde da população;

III - causar poluição hídrica que torne necessária a interrupção do abastecimento público de água de uma comunidade;

IV - dificultar ou impedir o uso público das praias;

$\mathrm{V}$ - ocorrer por lançamento de resíduos sólidos, líquidos ou gasosos, ou detritos, óleos ou substâncias oleosas, em desacordo com as exigências estabelecidas em leis ou regulamentos:

Pena - reclusão, de um a cinco anos.

§ 3o Incorre nas mesmas penas previstas no parágrafo anterior quem deixar de adotar, quando assim o exigir a autoridade competente, medidas de precaução em caso de risco de dano ambiental grave ou irreversível. 
Feitas as considerações pertinentes, há se se ressaltar que, de fato, resulta impossível transporem-se os institutos dogmáticos elaborados com base no direito penal primário ao direito penal secundário sem ajustes e críticas necessárias. Parece intuitivo que os critérios de análise da censurabilidade da conduta e, por consequência, da culpabilidade penal, deve ser distinto quanto se está diante de tipos penais de setores também diferentes.

Não se trata aqui de instituir privilégios e apregoar leniência à repressão dos crimes econômicos, mas de assumir um compromisso científico de revisitação de institutos forjados em circunstâncias históricas específicas e a partir dos influxos do direito penal nuclear.

A questão do exame da juridicidade da ação fomenta o desenvolvimento de teorias extremas: ora excessivamente rigorosas, a exigir exame antecipado da juridicidade da cada ação praticada na vida social, como requer o Supremo tribunal Federal alemão, ora tão brandas a excluir a possibilidade real de informação no caso de ausência de dúvida sobre a proibição na consciência do autor, consoante prescreve Horn ${ }^{66}$.

A partir destas premissas, deflui-se que o erro inevitável se afigura mais comum no âmbito do direito penal especial, na medida em que o cidadão ordinário possui maiores dificuldades na identificação do injusto concreto, assim como os profissionais da área desconhecem a absoluta integralidade das incriminações existentes. Por outro lado, no que concerne ao direito penal comum, avultam os

66 CIRINO DOS SANTOS, Juarez. Direito Penal - Parte Geral. 4. ed. Florianópolis: Conceito Editorial, 2010, p. 307. 
erros evitáveis, salvo quando inexiste razão para análise da juridicidade da conduta ${ }^{67}$.

Segundo Muñoz Conde, embora não se possa olvidar as preocupações com o tipos delitivos tradicionais, a atenção dos penalistas deve também ser endereçada a outros setores do Direito Penal que vêm galgando importância apenas recentemente e que, por outro lado, estão sendo objeto de complexas regulações legais dificilmente reduzíveis aos velhos moldes utilizados na dogmática tradicional, como, por exemplo, ocorre com os crimes contra a Fazenda Pública ${ }^{68}$.

Demonstra a experiência que é comum atribuir relevância ao erro quando se trata de normas ditas artificiais ou eticamente indiferentes, mas o tratamento é antagônico quando o erro se refere a normas constituintes do núcleo da sociedade.

Ocorre que o largo fenômeno de regulação econômica por meio de normas de Direito Penal impõe uma mudança de perspectiva, pois a complexidade técnica e a indeterminação deste novo arsenal normativo são suas características marcantes, a ensejar uma espécie de compensação do ponto de vista subjetivo, conferindo-se maior relevância ao erro do sujeito sobre a norma ${ }^{69}$.

Em outras palavras, a depender da conduta que se está a analisar, o "termômetro" da inevitabilidade do erro deve ser qualitativamente graduado.

67 Idem,, p. 308.

68 MUÑOZ CONDE, Francisco. El error en Derecho Penal. Buenos Aires: Rubinzal-Culzoni, 2003, p. 91.

69 Idem, p. 182. 
A questão do erro de proibição e da análise de seus contornos depende, primeiramente, da análise do delito em voga e a sua classificação como crime em si ou como crime de mera criação legislativa. De fato, a distinção entre os grupos de injustos repercute diretamente na estruturação dogmática correspondente ${ }^{70}$.

De fato, grande é a repercussão sobre a teoria do erro de proibição da distinção apontada entre in se e mere prohibita, centrada nos limites da legítima intervenção do direito penal, no conceito material de crime, bem como no consenso acerca dos valores sociais a serem protegidos das ofensas mais gravosas. Ora, é da experiência ético-prática sobre o âmbito do punível que se alimenta o cidadão em sua avaliação profana sobre a (i)licitude de certa conduta ${ }^{71}$.

Não haveria como ser diferente, posto que o agente, que vive em certo contexto regido pela norma jurídica penal é também, de maneira ativa, um intérprete de norma. E desta tarefa exegética somente se desincumbe se lançar mão de seus valores e princípios próprios, os quais conferirão significado às situações vivenciadas.

A dita expansão do Direito Penal sobre áreas antes por ele intocadas gera uma proliferação de delicta mere prohibita, o que

70 Augusto Silva Dias defende, a partir da teoria das grandes normas de comportamento, a diminuição do espaço de aplicação do erro sobre as proibições da parte final do art. 16, n. 1 do Códio Penal Português. DIAS, Augusto Silva. $<$ Delicta in Se $>$ e $<<$ Delicta Mere Prohibita $>$ Uma Análise das Descontinuidades do Ilícito Penal Moderno à Luz da Reconstrução de uma Distinção Clássica. Coimbra: Coimbra Editora, 2008, p. 19.

71 Idem, p. 34. 
repercute sobremodo no redimensionamento do princípio do error juris nocet $t^{2}$.

Ademais, conclui-se que a solução da problemática relativa ao erro de proibição não pode - e nem deve - ser homogênea, pois vinculada ao contexto do sentido social do comportamento. Ao lado de condutas lastreadas em representações ético-sociais correntes, outras há destituídas daquela qualidade ${ }^{73}$.

Assim, nas hipóteses de delitos de mere prohibita, a presença da consciência da ilicitude, para fins de culpabilidade, não prescindiria do conhecimento da própria norma formal incriminadora. Isto porque não se pode exigir do agente o conhecimento de valoração leiga do conteúdo incriminador quanto este está apartado das valorações éticosociais vigentes.

\section{CONCLUSÃO}

O Direito Penal, por certo, não está imune a esta mudança de balizas e de comportamentos sociais. Ao revés, influencia-a e é por ela também influenciado. Se o direito é produto do homem e regula a convivência social, a sua exegese é informada pelos contextos de sua gênese e de sua aplicação.

72 Ressalte-se a superação, na doutrina moderna, da errônea equiparação entre o erro de proibição e o erro de direito, o que trairia para aquele o antigo princípio romano aplicável a este, qual seja, do error juris nocet. CORREIA, Eduardo.

Direito Criminal. v. I. Coimbra: Almedina, 2008, pp. 409-410.

73 DIAS, Augusto Silva. << Delicta in Se >> e << Delicta Mere Prohibita >> Uma Análise das Descontinuidades do Ilícito Penal Moderno à Luz da Reconstrução de uma Distinção Clássica. Coimbra: Coimbra Editora, 2008, p. 36. 
Ademais, verifica-se ainda uma crescente administrativização do direito penal: ao lado de um direito penal primário consolida-se um direito penal secundário, baseado em imperativos de necessidade/utilidade.

Somente através de uma lei incriminadora, legitimamente produzida, é que se tem um tipo legal de delito. Apenas a partir da gênese da lei de incriminação é que o ilícito penal demonstra a sua face de ilícito ético socialmente desvalioso.

O direito penal passou a regular condutas e atingir áreas antes imunes à sua intervenção. Forte no princípio da intervenção mínima ou da ultima ratio, o direito penal em sua feição clássica servia à tutela dos bens jurídicos mais relevantes e caros à sociedade em determinada época histórica.

Ademais, os tipos penais passaram a ser utilizados como reforço de proibição de condutas antes apenas sancionadas na órbita administrativa. Olvidando seu caráter naturalmente fragmentário, as normas penais punitivas foram e são usadas para a regulação de certos subsistemas sociais.

A conclusão do presente estudo não é pela absoluta impossibilidade de aplicação de conceitos da teoria geral do delito ao direito penal econômico, mas pela inviabilidade de aceitá-los sem maiores digressões doutrinárias e sem as necessárias adaptações. Ademais, a questão da legitimidade não está - e nem poderia estar afastada dos debates sobre o direito penal econômico e sua análise é indispensável ao estudo da matéria. Entretanto, intolerável a ideia de que as categorias dogmáticas lhe seriam aplicáveis sem quaisquer questionamentos ulteriores, mormente quando se trata do erro de proibição e do conteúdo da cognoscibilidade necessária à reprovação penal. 
De há muito a doutrina penal vem tratando da distinção entre os delicta in se e os delicta mere prohibita para significar o discrímen entre os crimes com conteúdo ético auferido da comunidade e aqueles crimes de mera proibição e natureza utilitarista.

No que se refere aos crimes em si, a tipificação é mera conformação legal de condutas indesejadas pelo senso comunitário. Há certos bens jurídicos - vida, integridade física, patrimônio, etc. - que gozam de uma expectativa coletiva de proteção por serem tidos por valiosos e dignos de proteção a priori. $\mathrm{O}$ anseio por sua tutela penal emana dos recônditos da coletividade e é colhido pelo legislador, plasmando-o numa figura típica. Na formação destas figuras delituosas, mostra-se uma legítima intervenção do direito penal. Diga-se: do direito penal liberal, cujos contornos foram definidos por influências das ideias iluministas e de proteção do indivíduo, produtor e destinatário final da norma.

A mera positivação de uma conduta como penalmente ilícita não lhe confere eticidade, pois o conteúdo ético não surge do mero atuar formal do legislador. Ao revés, a conduta tipificada recebe as marcas social-valorativas, a racionalidade social, que ela transporta consigo.

Admitir um conhecimento da antijuridicidade formal como pressuposto da culpabilidade implicaria, no âmbito do direito penal de justiça, em aumento da impunidade, solução absolutamente inaceitável. Ora, nas figuras delitivas em que há um conteúdo ético expressivo, o sentido da desvalia é reconhecimento pela coletividade em geral, de modo que basta o conhecimento ou sentimento da danosidade social. Por outra banda, exigir o conhecimento da norma legal é tornar o conhecimento da ilicitude acessível apenas aos juristas 
e à parcela da população que possui o dever de informação para o exercício de uma profissão ou atividade específica.

Neste sentido, o recurso ao esforço de consciência é válido para aquilatar a potencial consciência da ilicitude em situações específicas em que as condutas tipificadas apresentam relevante conteúdo ético. O Código Penal alemão entendia-o como a utilização de todas as representações morais de valor, unidas a todas as forças espirituais de conhecimento, à tensão das forças da compreensão com a reflexão, informações e conhecimento necessários. No bojo da atividade intelectual, o esforço de consciência importa no reconhecimento de um sentido ético da conduta já anteriormente introjetado pelo sujeito. Entretanto, este critério não tem valia para todos os aspectos da consciência da ilicitude, mas somente para aquelas figuras típicas que representam condutas valoradas como merecedoras de castigo, pois seria possível ao sujeito refletir sobre os valores e obter a consciência da ilicitude. Em outras áreas, desaparece a relevância do esforço de consciência e a reprovação se fundamenta, apenas, por uma falha intelectual do sujeito que não fez todo o razoável para obter os necessários esclarecimentos e informação sobre a antijuridicidade da conduta.

A tipificação de comportamentos que não representam relevante ofensa acabam por prejudicar a percepção dos cidadãos e dificultar a difusão da informação indispensável para a legítima reprovação penal. Um erro sobre a ilicitude ocorre quando o agente não atinge a apreensão do desvalor do fato porque intercede (por razões imputáveis ao sujeito ou não) uma diversa valoração. Ainda que fosse possível ao agente conhecer o desvalor penal do fato e a ilicitude da sua conduta, não logrou alcançar o significado e agiu em contrariedade ao direito. 
São variegados os tipos penais em que ilícito típico é materializado de maneira forte, em razão da efetiva ofensa ao bem jurídico ou pela configuração ética do comportamento. Em outro viés, há tipos penais que revestem maior grau de formalização, acessório em relação à previsão de natureza administrativa, a qual define os âmbitos de permissão e proibição da conduta. Tal discrepância é produto da necessidade de se prever tipos penais para a tutela de bens jurídicos não vinculados diretamente às necessidades mais básicas dos tutelados, mas a subsistemas socioeconômicos que lograram projeção em momento histórico mais recente. O esforço de informação e reflexão, sem dúvida, possui grande relevância quando se está diante de tipos penais que encerram conteúdos éticos socialmente conhecidos e aceitos

Em regra, o instrumental da imputação penal e da culpabilidade defluem do Direito Penal primário, desenvolvidos sob o influxo iluminista, e se adaptam muito melhor às espécies delituosas clássicas do que às espécies normativas integrantes do direito penal econômico. O mesmo acontece com o dolo e a consciência da antijuridicidade. Uma larga quantidade de delitos suscitam a análise da consciência da ilicitude, o que revela, no âmbito do direito comparado, heterogeneidade nas respostas oferecidas, desde a absoluta irrelevância até a total relevância, passando por estados de relevância ou irrelevância relativa, do problema da consciência da ilicitude para a aferição da culpabilidade do agente.

Especificamente, no bojo do direito penal econômico, a maioria dos tipos são proibições de natureza formal, sem conteúdo ético relevante, a exemplo do artigo 69, da Lei n. 8.078/90 (Código de Defesa do Consumidor). Ora, o conhecimento da norma penal exemplificada não está ao alcance dos cidadãos em geral pelo simples processo de 
socialização, qual seja, pela obtenção de conhecimentos e de funções direta ou indiretamente calcadas na divisão do trabalho. Ao agente comum, não ligado diretamente às demandas da publicidade ou da prestação de serviços ou produtos ao consumidor, parece impossível adquirir a consciência do sentido da proibição acima exposta, salvo através do conhecimento formal da norma legal proibitiva.

Entende-se não ser possível a aplicação dos institutos dogmáticos elaborados com base no direito penal primário ao direito penal secundário sem ajustes e críticas necessárias. Não se trata aqui de instituir privilégios e apregoar leniência à repressão dos crimes econômicos, mas de assumir um compromisso científico de revisitação de institutos forjados em circunstâncias históricas específicas e a partir dos influxos do direito penal nuclear.

O erro escusável ou inevitável é mais disseminado no âmbito do direito penal especial, pois o cidadão ordinário possui maiores dificuldades na identificação do injusto concreto, assim como mesmo os profissionais da área desconhecem a absoluta integralidade das incriminações existentes. Por outro lado, no que concerne ao direito penal comum, avultam os erros evitáveis, salvo quando inexiste razão para análise da juridicidade da conduta. Informam as regras de experiências que é usual atribuir relevância ao erro quando se trata de normas ditas artificiais ou eticamente indiferentes, mas o tratamento é distinto quando o erro se refere a normas constituintes do núcleo da sociedade.

Entretanto, o fenômeno de regulação econômica por meio de normas penais impõe uma mudança de perspectiva, pois a complexidade técnica e a indeterminação destas são suas características marcantes, a ensejar uma espécie de compensação do ponto de vista subjetivo, conferindo-se maior relevância ao erro do 
sujeito sobre a norma. Com efeito, grande é a repercussão sobre a teoria do erro de proibição da distinção apontada entre in see mere prohibita, centrada nos limites da legítima intervenção do direito penal, no conceito material de crime, bem como no consenso acerca dos valores sociais a serem protegidos das ofensas mais gravosas. O expansionismo penal sobre áreas antes por ele intocadas gera uma proliferação de delicta mere prohibita, o que repercute sobremodo no redimensionamento do princípio do error juris nocet.

Assim, chega-se à conclusão de que a solução da problemática relativa ao erro de proibição não pode - e nem deve - ser homogênea, pois vinculada ao contexto do sentido social do comportamento. Ao lado de condutas lastreadas em representações ético-sociais correntes, outras há destituídas daquela qualidade. Por consequência, nas hipóteses de delitos de mere prohibita, a presença da consciência da ilicitude, para fins de culpabilidade, não prescindiria do conhecimento da própria norma formal incriminadora. Isto porque não se pode exigir do agente o conhecimento de valoração leiga do conteúdo incriminador quanto este está apartado das valorações ético-sociais vigentes.

\section{REFERÊNCIAS}

ARISTÓTELES. Ética a Nicômaco. Tradução de Leonel Valhandro e Gerd Bornheim da versão inglesa de W. D. Ross. v. 4. In: Pensadores. São Paulo: Nova Cultural, 1973. 
BRODT, Luís Augusto Sanzo. Da Consciência da Ilicitude no Direito Penal Brasileiro. 1. ed. Belo Horizonte: Del Rey, 1995.

CEREZO MIR, Jose. Derecho penal. Parte General. Buenos Aires: B de f, 2008.

DIAS, Augusto Silva. $<<$ Delicta in Se $>$ e $<<$ Delicta Mere Prohibita $>>$ Uma Análise das Descontinuidades do Ilícito Penal Moderno à Luz da Reconstrução de uma Distinção Clássica. Coimbra: Coimbra Editora, 2008.

DIAS, Jorge de Figueiredo. Direito Penal. Parte Geral. Tomo I. 2. e. Coimbra: Coimbra Editora, 2007.

. O Problema da Consciência da Ilicitude em Direito Penal. 5. ed. Coimbra: Coimbra Editora, 2000.

LUZÓN-PEÑA, Diogo Manuel. Curso de Derecho Penal: Parte General I. Madrid: Universitas, 1996.

MEZGER, Edmund. Tratado de Derecho Penal. T. II. Madri: Revista de Derecho Privado, 1935.

MIR PUIG, Santiago. Derecho Penal. Parte General. 9. Ed. Buenos Aires: B DE F, 2004.

MUÑOZ CONDE, Francisco. El error en Derecho Penal. Buenos Aires: Rubinzal-Culzoni, 2003. 
PINTO, Frederico de Lacerda da Costa. Erro e Consciência da Ilicitude em Infrações contra o Mercado de Valores imobiliários. Direito Penal Económico e Europeu: Textos Doutrinários. v. III. Coimbra: Coimbra Editora, 2009.

RODA, Juán Córdoba. El conocimiento de la antijuridicidad em la teoría del delito. Barcelona: Bosch Casa Editorial, 1962.

ROXIN, Claus. Funcionalismo e Imputação Objetiva no Direito Penal. Trad. Luís Greco. Rio de Janeiro: Renovar, 2002

SETTON, Maria da Graça Jacinto. A particularidade do processo de socialização contemporâneo. Disponível em http://www.scielo.br/scielo.php?pid=S010320702005000200015\&script=sci arttext. Acesso em 16/05/2015.

TOLEDO, Francisco de Assis. Culpabilidade e a problemática do erro jurídico penal. São Paulo: Revista dos Tribunais, 517/251, nov. 1978

. Erro de Tipo e Erro de Proibição no Projeto de Reforma Penal. RT, 578/295. 